Liudmila Zhuravlova, Ph.D., Lecturer, National Pedagogical Dragomanov University, Kiev

\title{
PRIORITIES AND CONTRADICTIONS OF GEORGE HERBERT WALKER BUSH SPACE POLICY
}

The article analyzes the basic principles of US space policy which developed at the end of the 1980's. The main focus is made on the detection and investigation of the priority of space component in the general political course of the republican administration of George $H$. W. Bush.

The article analyzes the process of revision the objectives of the United States space program by the American leadership and highlights the place and role of the commercial component in this process. The basic tools and methods of US space policy in the commercialization of space activities have been characterized. Unlike the other presidents before him, George H.W. Bush has put the space program on the agenda from the beginning of his presidency. The ambitions and large-scale plans of the President have been embodied in the Space Exploration Initiative 1989, including, among other things, the tasks of a manned flight and landing a man on Mars. It is determined that the result of George. H.W. Bush's announcement of such a costly and technically complex space program has become a confrontation along the lines of the president - NASA, president-Congress, which received the indicative name «Mars Wars».

As far as it is concerned, the US space program of George. H.W. Bush's presidential administration had a high priority and it laid the foundation for the reviewing fundamental principles of the American space policy by next administrations.

Key Words: the US Space Policy, George H.W.Bush, peaceful use of space, corporatization of space, Cosmic Research Iniciative.

УДК 94 (73)

http://doi.org/10.17721/2521-1706.2017.03.144-152
Михайло Кірсенко, доктор історичних наук, професор, Національний Університет «Києво- Могилянська академія»

\section{ЄВРОПЕЙЦІ У ВІЙНІ ЗА НЕЗАЛЕЖНІСТЬ СПОЛУЧЕНИХ ШТАТІВ АМЕРИКИ}

\begin{abstract}
Анотація. Розглянуто вплив Просвітництва на війну за незалежність США $i$ участь європейців. 3-поміж мислителів Славетної Революиії згадано конституційні ідеї Локка про взаємну відповідальність правителів і підданців й поділ між трьома гілками влади. Томас Пейн прибув з Англії та надихнув американських бориів за свободу доказами прав і обов'язку народу чинити опір утискам. Простежено радикалізацію Революиії, розвиток ї̈ зовнішньої політики. США вперше замінили засаду сюзеренітету монарха на суверенітет нації, впровадили іррегулярну тактику та іррегулярну дипломатію, користали з колоніальних суперечностей, аби здобути фінансову підтримку, постачання зброєю $і$ пряму допомогу від Франиії та забезпечити міжнародну ізоляцію Великої Британії. Ліберали і військовики Свропи відіграли чільну роль у привабленні громадської думки на бік американиів, налагодженні воєнної інфраструктури, навчанні піхоти $i$ кінноти, перетворенні добровольчої міліиії на регулярну армію і флот Континентального Конгресу. Корисно порівняти взаємовпливи Американської та Французької революиї за документами $і$ життєписами. Французи Лафаєт, Бомарше $i$ Рошамбо, поляки
\end{abstract}


Костюшко і Пулавський, німеиь Штойбен, шотландеиь Пол Джонс, численні друзі юної начії сприяли перемозі. Джордж Вашингтон, Бенджамен Франклін та інші Батькизасновники США високо цүінували цүі самовіддані та чинні зусилля.

Ключові слова: США, револючія, Континентальний Конгрес, Франція, незалежність.

Подеколи начебто суто наукові й не пов'язані з сучасністю питання набувають політичного сенсу. Це, зокрема, вплив іноземців на національну історію. В здобутті незалежності Сполученими Штатами поряд зі свідомими патріотами i ворогами-лоялістами дедалі помітніше нещодавні прибульці зі спадком Свропи в неосяжних обріях Нового Світу. Українській історіографії досі бракує уваги до цих осіб, тож зробімо крок до пізнання величезного внеску небагатьох людей (non multa sed multum) до визволення Америки.

Зараз американці переймаються труднощами, що їм завдають нелегали, але самі є нацією іммігрантів. Вони відзначають День Колумба, а поступово згадали вікінгів, корінних індіанців (natives) і ескімосів (Inuit). Неподалік від Білого Дому у Вашингтоні $є$ музеї культур тубільців і афро-американців, а в Думбартон-Окс експозиція лише на перший погляд несполучного мистецтва Візантії й МесоАмерики. Прагнення свободи і підприємництва вабили за океан європейців, які всотали засади Реформації та ліберальний раціоналізм Просвітництва. Заможні колоністи Америки вдалися до зброї 1773 року не з утисків, адже платили менше будь-кого в Свропі, крім поляків. Обурила дискримінація: податки ухвалював у Лондоні Парламент, де колоністи не мали депутатів. А неподільність прав i обов'язків прищепилась у свідомості.

3 Англії педагог і філософ-картезіанець, емпірик і сенсуаліст Джон Локк (John Locke, 1632-1704) справив вплив на Вольтера, Руссо, шотландців, німців і Америку трактатами про урядування та іншими творами. Апологет конституційної монархії, громадянського суспільства, відокремлення Церкви від держави, централізму (federative power) 3 питань війни і миру, він вперше обстоював поділ влади на законодавчу, виконавчу і судову гілки. Народ має повстати проти деспотизму тиранії. Держава мусить забезпечити природні права (на життя, особисту свободу, приватне майно) і закони (задля безпеки) та карати порушників. Люди делегують прерогативи компетентному урядові з загальної згоди і забирають назад в разі сваволі. Лібералізм не вадив Локку бути інвестором работоргівлі та виправдати вилучення земель в індіанців.

Англієць Томас Пейн (Thomas Paine, 1737-1809) в Америці 31774 року, редактором журналу картав работоргівлю, видав масовим накладом памфлет “Здоровий глузд” (Common sense) 1776 року і обгрунтував незалежність. Він став до лав Континентальної армії, надихав вояків низкою прокламацій зі схвалення Джорджа Вашингтона. Пейн вперше вжив назву Сполучені Штати Америки, [1, С.24] в складі делегації повсталих колоній вів переговори 1781 року з Францією, одержав будинок від штату Нью-Йорк, нагороди Конгресу і Пенсильванії. В Англії за його проектом 1790 року збудовано міст. В Парижі Пейн видав газету “Республіканець”, вивчав аграрний лад і фінанси, як депутат Конвенту брав участь у розробці Конституції й мало не наклав головою за Терору [2, С. 45], визволений завдяки послові Монро повернувся до Америки i підтримував свого другапрезидента Томаса Джеферсона. 
У Семирічній війні британці загарбали Французьку Канаду 1763 року, одразу почалися сварки колоній з Лондоном, і Людовик Шістнадцятий читав звіти агентів 3 Америки. Спочатку революціонери не наважилися просити допомоги інших держав, бо в разі компромісу наразилися би на звинувачення 3 державної зради. Пленум Континентального Конгресу вів зовнішні зносини і восени 1775 року утворив Комітет для таємної кореспонденції з друзями колоній у Великій Британії, Ірландії та інде. Це прототип міністерства закордонних справ чи Державного Департаменту США. Призначенню послів зазвичай передує запит на агреман, але іррегулярна дипломатія виряджала неформальних представників без попередньої процедури. Навесні 1776 року до Парижу прибув член Конгресу Сайлас Дін 3 кількома колегами. [3, С. 68 ]

Репресії британців спонукали до розриву з метрополією. Конгрес ухвалив Декларацію Незалежності 4 липня 1776 року з їі причин і мотивів, що Бог створив людей рівними і “наділив певними невід’ємними правами, до яких належить життя, свобода і прагнення щастя, що уряди встановлено людьми на забезпечення цих прав, а влада урядів походить зі згоди тих, ким керують, що в кожному разі, коли якась форма правління стає згубною для цієї мети, народ має право змінити чи скасувати ії та встановити новий уряд, спираючись на ті засади.., які здаються народові найдоцільнішими.., а коли довга низка зловживань... виявляє намір підпорядкувати народ абсолютному деспотизмові, народ має право і обов'язок повалити цей уряд".

Уряд Франції не бажав компрометуватися відвертим співчуттям заколотові й доручив делікатну місію авторові “Севільського цирульника" і "Одруження Фігаро". Бомарше (Pierre-Augustin Caron de Beaumarchais, 1732-99), лагодив годинники аристократів, навчав доньок монарха гри на арфі. Цей драматург, дипломат і фінансист заснував фіктивний торгівельний дім "Родріго Горталес і Ко" (1776-83), і Дін надіслав за океан одяг 20 тис. вояків, 30 тис. мушкетів, 200 гармат, 100 тон пороху на 21 млн. ліврів, одержаних від Франції та за продаж краму Америки. Іспанія надала допомогу на 300 тис. доларів. Щирий друг повстанців, Бомарше придбав зброї на 3 млн. ліврів і не казав про зв'язки з урядом Дінові, колега якого потай інформував Лондон.

Навесні 1777 року виник Комітет, а з 1781 року Департамент іноземних справ. (Подвійні функції Державного секретаря, керівника дипломатії й заступника голови уряду, як у Генерального писаря Війська Запорізького.) У Франції послом став єдино знаний Європі американець. На протест британців міністр Вержен відповів, що лист до Нанту з забороною приїзду не знайшов адресата, і нечемно виганяти його 3 Парижу. Поштмейстер, друкар, демократ i ворог рабства Бенджамен Франклін (Benjamin Franklin, 1706-90) заснував першу бібліотеку США, Філософське товариство, Філадельфійську академію (нині Пенсільванський університет). Винахідник, фізик-дослідник електрики, метеоролог, економіст, дизайнер Державної печатки, масон ложі “Дев'ятеро Сестер”, член кількох Академій, тільки він підписав усі чільні документи незалежності: Декларацію, Конституцію США і Версальський мир 1783 року.

Британські крейсери перехоплювали судна, зафрахтовані фірмою Горталес, i Франклін з колегами в грудні 1776 року першою дипломатичною нотою в історії США пропонували Франції союз та прохали захисту торгівлі. Граф Вержен обіцяв таємну допомогу і справді надав великі кошти, а лінійні кораблі та фрегати 
вирушили до Америки. Уряди в Мадриді, Берліні, Відні, Гаазі, Петербургу не квапилися визнавати посланців США, але спостерігали і користали з труднощів Лондону. В лютому 1780 року Росія оприлюднила Декларацію морського озброєного нейтралітету про право торгувати 3 воюючими країнами, за винятком явної контрабанди і реально блокованих портів. Російський флот вийшов у море, а держави Європи утворили Лігу морського озброєного нейтралітету. Франція, Іспанія і США формально не прилучились до Декларації нейтралів, але поділяли їі засади.

В Нью-Йорку і містах Нової Англії є чимало візуальних нагадувань про Пілігримів 3 "Mayflower" та інших Отців-Пілігримів, а в містечках прерій (Great Mid-West) статуї піонерів-фермерів і вояків. Столиця і округ Колумбія рясніє пам'ятками Отців-Засновників. Президент-парк навколо Білого Дому охоплює галявину Еліпс з Нульовою милею і майдан, де були ринок рабів, цвинтар, іподром, бівак і вже двісті років парк. В центрі між чотирьох гармат кінна статуя президента-кельта Джексона (Andrew Jackson), співзасновника Демократичної партії, переможця британців і семінолів. Назва Лафаєт-сквер $є$ на честь Героя двох світів і Трьох революцій (в Америці та у Франції), по кутках пам'ятники іноземцям-борцям за незалежність США - сам Лафаєт, Костюшко, Штойбен і Рошамбо. На честь їх названо міста, вулиці, парки, гори, мости, школи, станції, кораблі, свята в Америці, Свропі, Австралії.

Син померлого в Семирічній війні полковника-лицаря Ордену св. Людовика, маркіз де Лафаєт (Marie-Joseph Paul Yves Roch Gilbert du Motier, marquis de La Fayette, 1757-1834) мав ім'я Жільбер в пам'ять свого предка-соратника Жанни д’Арк. Випускник колежу Плессі (згодом Ліцей Людовика Великого), спадкоємець діда-капітана гвардії маркіза де ла Рів'єр, він ще підлітком був лейтенантом Чорних мушкетерів, невдовзі став командиром кавалерійського полку Ноайль, зятем герцога д'Аєн і капітаном у фортеці Мец. Восени 1776 року на обіді в командувача округу маршала де Бройля юнак почув розповідь Вільяма Генрі Глостера, як люди 3 Бостону вимагають свободи тринадцяти колоніям в Америці. Наступного дня герцог Глостер прочитав французам лист з Лондону про Декларацію Незалежності США.

Лафаєт запропонував Франклінові, що служитиме без оплати в армії Континентального Конгреса, взяв відпустку і навесні 1777 року на власному кораблі "Перемога" (Victoir) вирушив до Америки, став ад'ютантом Джорджа Вашингтона і генерал-майором. Француз статечно воював, бував пораненим, своїм коштом спорядив дивізію, командував Північною армією, порозумівся 3 індіанцями, збудував за власні гроші форт з гарматами на межі з Канадою і дав відсіч вдвічі численнішому ворогові. Захворівши на запалення легенів, він був тріумально зустрінутий в Парижі наприкінці 1778 року, де королева Марія Антуанета домоглась йому звання полковника. Маркіз дуже сприяв французькій допомозі США і мирним переговорам $1781-83$ років у Парижі.

Обраний від шляхти до Генеральних Штатів 1789 року, Лафаєт наполягав на співпраці станів, пропонував робити “Декларацію прав людини і громадянина" за американським взірцем, демократизував своє прізвище після штурму Бастилії, заснував клуб конституційних монархістів-фельянів, командував Національною гвардією і загоном на кордоні, проте наразився на закиди від роялістів зі зради за поміркованість, а від монтаньярів за розстріл повстання 1791 року. [4, С. 2] 
Противник терору, він втік і був в'язнем в Австрії, протестував проти диктатури Наполеона, відмовився стати пером Імперії, за реставрації Бурбонів був опозиціонером у Палаті депутатів, під час Липневої революції 1830 року переконав Париж підтримати Луї-Філіпа, вважав Францію не готовою до республіканського ладу, але не був у захваті 3 Орлеанської монархії. Франція шанує його принциповість і чесність. [5, С. 6]

У штабі Лафаєта в Олбані був Костюшко (Andrzej Tadeusz Bonawentura Kościuszko, білор. Андрэй Тадэвуш Банавентура Касьцюшка, лит. Tadas Kosciuška, 1746-1817). Цей хрещений в католицтві та православ’і праправнук двірського писаря Великого князівства, кам'янецького боярина Костянтина (звідси прізвище) Федоровича і Ганни Ольшанської з княжого роду (шлюби предків 3 Ягайлом i Вітовтом), син шляхтича 3 Литовського Трибуналу, мечника Берестейського воєводства Людвика і Теклі Ратомської, вчився в єзуїтів, потім у лицарській школі в Казимірському палаці у Варшаві (нині там університет) під опікою князя Адама Казимира Чарторийського. Кадет на прізвисько “Швед” навчався фехтування, історії, фізики, арифметики, геометрії, вищої математики, політекономії, тактики, кавалерії, артилерії, латини, французької та німецької мов. Він став хорунжим, потім капітаном.

Брат Костюшка воював за Барську конфедерацію, а Тадеуш 1769 року поїхав в Академію мистецтв у Парижі, адже військові школи там не брали чужинців. Юнак зазнав впливу Просвітництва і фізіократів. Після поділу Речі Посполитої він 1774 року повернувся додому, вчив малювання доньок магната Юзефа Сосновського, одна 3 них згодилась на шлюб, але пахолки завадили втечі коханців. Тадеуш потерпав на безгрошів'я, хотів до Саксонії, а в Парижі довідався про події в Америці. Влітку 1776 року він зміцнив Білінгспорт на захист річки Делавер i Філадельфії, де засідав Другий Континентальний Конгрес. Волонтер Франкліна привернув увагу, Вашингтон за рекомендацією князя Чарторийського і генералів восени призначив його полковником інженерної служби. [6, С. 161-320; 430-440]

Навесні 1777 року Костюшко будував форти і табори на кордоні з Канадою, захищав фортецю Тикандерогу, у відступі затримав переслідувачів засіками i руйнував мости. Споруджені ним фортифікації понад Гудзоном дали змогу завдати нищівної поразки британцям восени біля Саратоги. Поряд з іншим, поляк збудував Форт Клінтон у штаті Нью-Йорк (військова академія Вест-Пойнт, де його статуя). Костюшко був другом Томаса Джеферсона (Thomas Jefferson, 1743-1826) і малював майбутнього третього президента в лавровому вінку. Конгрес 1783 року дав Костюшкові громадянство і звання бригадного генерала. Він одержав 2,5 кв. км. грунтів і гроші, визволив деяких чорношкірих рабів, став членом Американського Філософського товариства і одним $з$ трьох іноземців у престижному Товаристві Цинцинаті. [7, С. 39]

В Польщі Костюшко обмежив панщину в своєму маєтку. Коли Сейм збільшив армію, він 1789 року став генерал-майором. Злякана ліберальною Конституцією 3 травня 1791 року, Росія почала війну. Костюшко бився на чолі дивізії, після поразки закликав Париж проти Австрії та Пруссії. Після Другого Поділу він 24 березня 1794 року в Кракові склав присягу повстання на майдані, заклики до війська, громадян, священиків, жінок. Після перемоги при Рацлавицях і оборони Варшави він обіцяв Поланецьким універсалом волю селянам, в жовтні зазнав поразки при Мацейовицях і потрапив у полон. Павло Перший випустив його 1796 
року. Костюшко скорився, аби визволити тисячі бранців. У Франції він відхилив спокуси Наполеона і царя Олександра, бо ті не обіцяли Польщі давніх меж. Костюшко помер у Швейцарії. Біля статуї в Лафаєт-парку є постать польського повстанця-косинера. [8, С. 3]

Американців надихали шляхетні гасла, але сезонні роботи відволікали рільників. Іррегулярна тактика стрілянини 3-за живоплотів зарадила в малих сутичках, та добровольчій міліції важко витримувати вогонь і багнетні атаки загартованого війська Корони та іiі найманців, здебільшого 3 Гессену. Армію Конгресу впорядкували європейці. Барон фон Штойбен (Friedrich Wilhelm Ludolf Gerhard Augustin von Steuben, 1730-1794) з Магдебургу служив у Фридриха Другого, поранений в Семирічній війні пішов у відставку і прибув до Пенсильванії 1777 року. В битві при Монмуті влітку 1778 року він дав ладу, коли вояки розгубились, наступного року діяв у горах Нової Англії, 3 Лафаєтом стримав британців і дав змогу Вашингтонові продовжити облогу Нью-Йорка. [10, С.667669]. Пруссак став американським генералом за заслуги в навчанні війська і дожив віку в своєму маєтку в Пенсильванії.

На четвертому розі Лафаєт-сквер пам'ятник графові де Рошамбо (Jean-Baptiste Donatien de Vimeur, comte de Rochambeau, 1725-1807). Кавалерист, ад'ютант герцога Орлеана у війні за Австрійську спадщину, він командував гренадерами i лінійним полком, став командором Ордену св. Людовика. Коли Франція уклала союз зі США, корпус генерал-лейтенанта Рошамбо висадився на Род-Айленді, з'єднався 3 Вашингтоном біля Нью-Йорку, притиснув до моря в Йорктауні та змусив британську армію Корнуолліса скласти зброю 17 жовтня 1781 року. Капітуляція сприяла визнанню США. Конгрес подарував Рошамбо дві гармати. Генерал-губернатор Пікардії й Артуа став маршалом 1791 року за відбудову фортець Франції, ледь уник гільйотини. Ім'я лицаря Почесного Легіону Рошамбо на Тріумфальній Арці в Парижі. [11, С. 386-395]

На Майдані Свободи (Freedom Plaza) в столиці США $є$ статуя Казимира Пулавського (Kazimierz Michał Wacław Wiktor Pułaski, англ. Casimir Pulaski, 174679). Шляхтич герба Слеповрон, він 3 батьком і братами очолив Барську конфедерацію, звитяжно боронив Ченстохову, після поразки 1772 року втік до Парижу. Американці Франклін і Дін запросили його, дали рекомендацію. Влітку 1777 року поляк справив враження на Вашингтона. Легіон бригадного генерала Пулавського бився при Джермантауні та інде, рятував командувача. Соратник Міхал Ковач звав його Батьком кавалерії США. Поранений в атаці біля Саванни в Джорджії, він знепритомнів і вмер. [12, С. 147] Труну знайдено 1996 і поховано 2005 року. Конгрес 2009 року визнав Пулавського почесним громадянином США, один з сімох, вшанованих цією честю.

Пол Джонс (John Paul Jones, 1747-92) 3 Шотландії 3 юнги виріс до судновласника, прибув до Філадельфії, успадкував плантацію, а 31775 року лейтенантом Континентального флоту вів три кораблі. 3 Дувру під чорними вітрилами він здобув караван 3 платнею війська в Уайтхевені, потім на чолі американо-французької ескадри в п'ятнадцять вимпелів напав на Ліверпуль 1779 року. Людовик Шістнадцятий вручив йому золоту шпагу з діамантами і орден святого Людовика. Чорний Корсар дав кораблю назву-псевдонім друга Франкліна “Добряк Ричард” (Bonhomme Richard). Коли біля берегу Англії половина екіпажу 
загинула, він на вимогу здатись гукнув, що ще не почав бій (Sir, I have not yet begun to fight!), пішов на абордаж і взяв ворожий корабель.

Пол Джонс взяв 56 британських суден і скінчив Війну за незалежність коммодором на лінійному 74-гарматному кораблі "Америка". Потім одержав від Катерини Другої патент контр-адмірала 1788 року, командував ескадрою в ДніпроБузькому лимані, братався з запорожцями і в козацькому вбранні на кораблі "Володимир" воював проти турків, відмовився очолити Балтійський флот і помер консулом США в Парижі. [13, С. 512 ] Видані в Единбурзі його мемуари надихали пригодницькі твори Джона Фенімора Купера і Олександра Дюма. Герметичну труну 3 заспиртованим тілом засновника американського флоту 1905 року перевезено до США і в присутності президента Теодора Рузвельта поховано у військово-морській академії, де є статуя Пола Джонса.

Масонство на початку XVIII сторіччя розквітнуло в метрополії й дало пагони в Новому Світі, насамперед у Пенсильванії. Незалежний від Лондона осередок постав у Філадельфії за участі Франкліна. Виникали ірландські, шотландські, військові ложі. Отці-Засновники США були франкмасонами. Символікою Вільних Мулярів рясніють купюри доларів і мистецькі пам'ятки. Під впливом масонства майор у Війні за незалежність, француз-архітектор Ланфан (L'Enfant, Pierre Charles, 1754-1825) за взірцем Версалю розробив план забудови федеральної столиці, що гальмувався через чвари і набув обрисів у XX сторіччі. Величні храми масонів височіють у столиці (Church Street) та інде, а в Александрії у Вірджинії Національний меморіал Джорджа Вашингтона, де не бракує експозиції від Соломона і Хірама до низки моделей визначних споруд світу і рухливих фігурок людей різного фаху.

Поява США завершила формування світової системи міжнародних відносин XVI-XVIII століть у доланні європоцентризму. Американці читали Енциклопедію (L'Encyclopédie ou Dictionnaire raisonné des sciences, des arts et des métiers, 1751-72 ) просвітників Дідро (Denis Diderot, 1713-84) і Даламбера (Jean le Rond D’Alembert,1717-83). Парижани 1789 року писали “Декларацію прав людини i громадянина" і радилися 3 послом США Джефферсоном, автором Декларації Незалежності. Світ неподільний, нещодавно Президент Білл Клінтон у промові на Михайлівському майдані перед Дипломатичною Академією України процитував Тараса Шевченка: “Коли ми діждемося Вашингтона з новим і праведним законом? А діждемось-таки колись”.

Відсоток поляків переважав між іноземців у всіх революціях на Заході. Парадний зал Посольства Польщі у Вашингтоні оздоблює мистецьке панно, де в центрі постаті двох вершників: на передньому плані Ян III Соб'єський, а в серпанковій глибині маршал Юзеф Пілсудський на Каштанці. Цей перегук крізь два 3 половиною сторіччя виглядає несподіваним, а насправді має глибокий сенс. Адже нищівна перемога коаліції під проводом польського короля біля Відня 1683 року поклала край тискові Османів на Європу, а “Диво на Віслі” 1920 року розгромом Червоної Армії поляками біля Варшави за сприяння війська Української Народної республіки при Замості врятувало Європу від навали більшовиків. [14, C. 228] На вдячність полякам за сприяння свободі США, американці зібрали кошти і спорядили ескадрилью літаків, яка взяла участь у захисті Варшави і переслідувала Червону Армію. [9, С. 1] 
Мимоволі виникає аналогія 3 покликанням Сполучених Штатів, які зі своїм вступом до обох Світових війн вирішальним чином сприяли перемозі цивілізації. Американська Революція вперше на державотворчому щаблі висунула засаду суверенітету нації замість усталеного при абсолютизмі сюзеренітету “монархів 3 божої ласки". Волонтери з Європи відіграли тоді надзвичайно важливу роль у розбудові збройних сил США. Німець зміцнив свідомою дисципліною добровольчу армію Континентального Конгресу, французи стали при нагоді при витоках дипломатії та привели регулярний експедиційний корпус і ескадру, а шотландець започаткував військово-морський флот, поляки налагодили інженерну службу i кінноту.

Представлена тема має не лише суто наукове значення, бо звернено увагу на проблеми, досі не досліджені в українських істориків. Сподіваймося, що можливості доступу до публікацій та джерельних баз спонукають наших дослідників до їх поглибленого вивчення. Приклади взаємодопомоги у скруті мають протидіяти проявам ксенофобії і нетерпимості у сучасні непрості часи. Американці, попри брак власної тривалої історії, шанобливо ставляться до давнини. Перед будинком Національних Архівів у самому центрі столиці на граніті викарбовано: "Минуле - це пролог. Вивчаймо минуле".

\section{Список використаних джерел і літератури}

1. Paine T. The Complete Writings of Thomas Paine / Paine T. [Collected and Edited by Philip S. Foner, Ph. D.] - New York: The Citadel Press, 1945. - Vol. 1-2.

2. Пейн Т. Права людини / Т.Пейн - Львів: Літопис, 2000. - 255 с.

3. Chorlton T. The First American Republic 1774-1789: The First Fourteen American Presidents Before Washington /T. Chorlton. - Bloomington, Indiana: AuthorHouse, 2011. - P. 68.

4. An Officer in the Late Army. A Complete History of the Marquis de Lafayette: Major-General in the American Army in the War of the Revolution. - J. \& H. Miller. Publishers. 1858. - P. 504.

5. Clary D. Adopted Son: Washington, Lafayette, and the Friendship that Saved the Revolution. Bantam Books, 2007. - P. 6.

6. Herbst, S. Kościuszko Andrzej Tadeusz Bonawentura (1746-1817) / S. Herbst // Polski Słownik Biograficzny. - Wrocław; Warszawa; Kraków: Zakład Narodowy Imienia Ossolińskich Wydawnictwo Polskiej Akademii Nauk, 1969. - Tom XIV/3, zeszyt 62. - S. 161-320; 430-440.

7. Szyndler B. Tadeusz Kościuszko 1746-1817 / B.Szyndler. - Warszawa: "Bellona", 1991. 487.

8. Szyndler B. Tadeusz Kościuszko w literaturze narodów Europy i Stanów Zjednoczonych Ameryki Północnej / [Jerzy Śliziński]. - Warszawa : Wydawnictwo Ministerstwa Obrony Narodowej, 1981. -283.

9. Łydka A. Zapomniani sojusznicy wojny z bolszewikami. [Electronic Resource] - Mode of Access: http://www.polska-zbrojna.pl/home/articleshow/9206 (last access: August 2, 2017). - Title from the Screen.

10. Doyle F. Frederick William von Steuben and the American Revolution./ Doyle F.- New York, 1970. - P. 667-69.

11. Szczygielski W. Pułaski Kazimierz (1746-1779) / W. Szczygielski// Polski Słownik Biograficzny. - Wrocław - Warszawa - Kraków - Gdańsk - Łódź: Zakład Narodowy Imienia Ossolińskich, Wydawnictwo Polskiej Akademii Nauk, 1986. - T. XXIX/..., zeszyt 12...- S. 386395. (пол.)

12. Lenkiewicz A. Kazimierz Pułaski (1745-1779) / A.Lenkiewicz. - Wrocław: Wydawnictwo Biuro Tłumaczeń, 2004. - S. 147.

13. Морісон Д. П. Джонс. Біографія моряка / Д.Морісон. - Київ: Основи. - 2013. - 520 с.

14. Bołtuć M. Budienny pod Zamościem / M. Bołtuć. - «Bellona», 1997. - t.XXII. - Z. 3, S. 203229. 


\section{References}

1. PAINE,T. (1945) The Complete Writings of Thomas Paine. New York, The Citadel Press.

2. PAINE, T.( 2000) Prava Ludyny. Lviv: Litopys.

3. CHORLTON, TH.P (2011). The First American Republic 1774-1789: The First Fourteen American Presidents Before Washington. Bloomington, Indiana: AuthorHouse.

4. An Officer in the Late Army A Complete History of the Marquis de Lafayette: Major-General in the American Army in the War of the Revolution. (1858) J. \& H. Miller. PUBLISHERS.

5. CLARY, D. (2007) Adopted Son: Washington, Lafayette, and the Friendship that Saved the Revolution. Bantam Books.

6. HERBST,S. Kościuszko Andrzej Tadeusz Bonawentura (1746-1817). Polski Stownik Biograficzny. Wrocław; Warszawa; Kraków: Zakład Narodowy Imienia Ossolińskich Wydawnictwo Polskiej Akademii Nauk, 1969. Tom XIV/3, zeszyt 62.

7. SZYNDLER, B. (1991) Tadeusz Kościuszko 1746-1817. Warszawa: "Bellona", 1991.

8. ŚLIZINSKI, J. (1981) Tadeusz Kościuszko $w$ literaturze narodów Europy i Stanów Zjednoczonych Ameryki Pótnocnej. Warszawa: Wydawnictwo Ministerstwa Obrony Narodowej.

9. ŁYDKA, A. (2013) Zapomniani sojusznicy wojny z bolszewikami [Online] Available from: http://www.polska-zbrojna.pl/home/articleshow/9206 (Accessed August 2, 2017).

10. DOYLE, F. (1970) Frederick William von Steuben and the American Revolution. New York: Burt Franklin.

11. SZCZYGIELSKI, W. (1986) Pułaski Kazimierz (1746-1779). Polski Słownik Biograficzny. Wrocław -Warszawa - Kraków - Gdańsk - Łódź : Zakład Narodowy Imienia Ossolińskich, Wydawnictwo Polskiej Akademii Nauk.

12. LENKIEWICZ, A. (2004) Kazimierz Pułaski (1745-1779). Wrocław: Wydawnictwo Biuro Tłumaczeń.

13. MORISON, D.P. (2013) Jones, Biografia moriaka. Kyiv: Osnovy.

14. BOŁTUĆ, M. (1997) Budienny pod Zamościem. Warszawa: «Bellona».

Надійшла до редколегії 26.02.2017

Mykhailo Kirsenko, PhD (history), Professor, National Kyiv Mohyla Academy

\section{The Europeans in the USA War of Independence}

Abstract. The article regards the Enlightenment influence and European participation in the War of Independence. Among the Glorious Revolution thinkers attention is paid to constitutionalist John Locke ideas of mutual responsibilities of rulers and subjects, as well as division of three branches of power. Thomas Paine had come from England and inspired American freedom fighters with his arguments of rights and duty of people to resist tyranny and oppression. There is traced radicalization of the American Revolution, and its foreign policy gradual development. The USA replaced a principle of monarchic suzerainty with postulate of national sovereignty, practiced irregular tactics and irregular diplomacy using colonial contradictions to get crucial financial support, weaponry supplies, and direct assistance by France as well as promoting international isolation of Great Britain. The European liberals and military officers, plaid important role in attracting public opinion to America, organizing infrastructure, training infantry and cavalry, transforming voluntary militia into the Continental Congress regular army and navy. It is compared mutual influences of the American and French Revolution reflected in documents and biographies. The Frenchmen La Fayette, Beaumarchais and Rochambeau, Poles Kościuszko and Pulaski, German von Steuben, and Scotsman Paul Jones proved to be the most distinguished among foreign friends of the young nation contributing a lot to its victory. Their self-sacrificed and effective efforts were highly estimated by George Washington, Benjamin Franklin and other Fathers of the USA.

Key words: USA, France, American Revolution, Continental Congress, ,independence. 